\title{
The feelings inferiority of student in islamic junior high school
}

\author{
Afri Rahmadia Marta ${ }^{1}$, Daharnis Daharnis ${ }^{2}$, Syahniar Syahniar ${ }^{3}$ \\ ${ }^{123}$ Universitas Negeri Padang
}

\begin{tabular}{|c|c|}
\hline Article Info & ABSTRACT \\
\hline Article history: & Feelings of inferiority in the individual can interfere with his development. \\
\hline Received Nov $3^{\text {rd }}, 2018$ & Therefore, it is important to provide treatment through Guidance and \\
\hline Revised Nov $6^{\text {th }}, 2018$ & Counseling services. In order for the implementation of Guidance and \\
\hline Accepted Nov $12^{\text {th }}, 2018$ & $\begin{array}{l}\text { Counseling services to run effectively and efficiently, it is necessary } \\
\text { described the inferiority condition of individual accurately. This study aims }\end{array}$ \\
\hline Keyword: & $\begin{array}{l}\text { to describe feelings of inferiority student's in Islamic Junior High School. } \\
\text { The research methodology used is quantitative with a descriptive-analysis. }\end{array}$ \\
\hline Feelings of inferiority & $\begin{array}{l}\text { The research instrument used Likert scale model. Research subjects } \\
\text { amounted to } 38 \text { students. The results showed that the feelings inferiority of } \\
\text { student was in a medium category with a persentage } 50 \% \text {. }\end{array}$ \\
\hline
\end{tabular}

(C) 2018 The Authors. Published by Redwhitepress.

This is an open access article under the CC BY-NC-SA license

(https://creativecommons.org/licenses/by-nc-sa/4.0/

\section{Corresponding Author:}

Afri Rahmadia Marta

Universitas Negeri Padang

Email: afrirahmadiamarta@gmail.com

\section{Introduction}

The teenager is an icon that is synonymous with the transition from childhood to adulthood phase (Agbaria, Ronen, \& Hamama, 2012). Adolescences are also indicated as a period that seems quite risky, where some teenagers might have some difficulties to deal with various changes that occur in their lives. Regarding this, the adolescences possibly need multiple ranges of professional help in understanding their difference to achieve and complete their developmental tasks effectively and excellently (Papalia, Old, \& Feldman, 2011; Santrock, 2012).

It can be said that one of the most striking changes in adolescence is a change in their physical condition (Papalia et al., 2011). Richard et al. (Papalia et al., 2011) suggest that adolescents tend to dislike seeing themselves. Teenagers will have many assumptions that may feel they are less impressive than their counterparts. Feelings of dissatisfaction with their body image can lead to inferiority (Muhsin, 2014a). The study of Ekbote, Shimpi, Rairikar, Shyam, \& Sancheti (2017) in India found that $15.25 \%$ of the adolescent population had concerns about body image.

The Feeling of inferiority is a psychological condition experienced by humans. People might feel less worthy, less capable, helpless, self-pity as a form of compensation from the failure to achieve superiority (Adler, 1997; Brachfeld, 2001; Feist \& Feist, 2011; Feldman, 2012; Friedman \& Schustack, 2008). People who may have low self-esteem tend to be difficult in making decisions for their progress, and slowly they will marginalize themselves from their communities (Centi, 1993; Kaluzna, 2017; Kartika \& Nurihsan, 2009).

Erikson states that in adolescence, the students will face a phase, called "effort versus inferiority". If the teenagers pass this period effectively, then they will have a high sense of competence towards 
themselves. Nevertheless, if the teenagers fail to deal with this period, they might feel overrun by feelings of inferiority that negatively impact the next period (Feldman, 2012; Santrock, 2012).

Several factors that cause the emergence of inferiority feelings in adolescents are social relationships with peers (Min, Lee, \& Lee, 2014), socioeconomic status, parenting patterns (David \& Trandafira, 2012), confusion of self-identity (Papalia et al., 2011), anxiety, and physical form (Feist \& Feist, 2011; Hidayat, 2015; Hoang, Cytrynbaum, \& Scherer, 2017; Hurlock, 2008; Kaluzna, 2017; Suryabrata, 2012).

Data from the National Research Council (NRC) shows that children who come from low-income family and have low education tend to have high-level inferiority feelings compared to middle- and upperlevel children with adequate parental education (Papalia et al., 2011). In this case, Dornbusch, Ritter, and Robert (Papalia et al., 2011) found that among 6400 high school students in California showed self-pity attitudes caused by parental parenting.

Acute feelings of inferiority will cause to the emergence of inadequacy sense, feelings of worthlessness, and lack of self-confidence (Ferguson \& Hull, 2017; Jin et al., 2014). The result of Maharani \& Mansur (2016) discovered that the feeling of confidence in Junior High School students is still in the low category. This condition also probably leads to adverse impacts, such as the students becomes depressed, even tends to suicide, mental disorder, and self-destructive behavior (Iltizamah \& Sastroatmodjo, 2017). This research is considered important, because it can be used as a basis for guidance and counseling teachers in improving guidance and counseling services in schools, especially handling problems about feelings inferiority of students.

\section{Method}

In this study, researchers used descriptive research method. This research was conducted on students Madrasah Tsanawiyah in West Sumatera. Research subjects was consisted of male and female students. The researchers used the questionnaire as an instrument developed by researchers using a Likert scale models. The questionnaire consists of 29 item questions measuring the inferiority feeling based on physical condition, namely physical natural form, physical appearance, physical ability, and physical disability.

Respondents in this study were given five choices of tiered answer starting from scale 1 (very unsuitable) to 5 (very suitable) (Azwar, 2014). Reliability of the instrument was obtained from Cronbach Alpha calculation with coefficient $\alpha=0,921$. The result of validity test for variable feelings of inferiority with a coefficient of range 0,30 until 0,80 (Product Moment Correlation). For the research procedure, the researchers visit the school and provide the questioners to the students. Before they fill out and complete the questioners, the researchers give some brief explanations about the purpose of this study.

\section{Results and Discussion}

The results of this study were tested using descriptive analysis. Table 1 shows the meaning, percentage and standard deviation of variables research (inferiority feelings).

Table 1: Categorization The Feelings of Inferiority

\begin{tabular}{|c|c|c|c|}
\hline Interval Skor & $\%$ & Category & Frekuensi \\
\hline $107-145$ & $74-100$ & High & 3 \\
\hline $68-106$ & $47-73$ & Medium & 14 \\
\hline$<67$ & $\leq 46$ & Low & 21 \\
\hline & \multicolumn{2}{|c|}{ Total } \\
\hline
\end{tabular}

Based on Table 1 it can be seen that students' feelings of inferiority are grouped into three categories (High, Medium, and Low). As for the explanation is from 38 respondents given questionnaire then 3 students have a feelings inferiority in high category, 14 students have a feelings inferiority in medium category, and 21 students have a feelings inferiority in low category. The following details the description of feelings inferiority students based on indicators $(n=38)$. 
The feelings inferiority of student in islamic junior high school

Table 2: The Results of Feelings Inferiority Variable Analysis

\begin{tabular}{|c|c|c|c|c|c|c|c|c|}
\hline \multirow[t]{2}{*}{ No } & \multirow[t]{2}{*}{ Indicators } & \multicolumn{7}{|c|}{ Score } \\
\hline & & Maks & Min & $\sum$ & Average & $\%$ & $\begin{array}{c}\text { Deviation } \\
\text { Standar }\end{array}$ & Gloss \\
\hline 1 & $\begin{array}{l}\text { Natural physical } \\
\text { form }\end{array}$ & 34 & 8 & 646 & 17 & 49 & 7,1 & Medium \\
\hline 2 & $\begin{array}{l}\text { Physical } \\
\text { appereance }\end{array}$ & 37 & 11 & 790 & 21 & 52 & 5,6 & Medium \\
\hline 3 & Physical ability & 32 & 12 & 718 & 19 & 54 & 5,3 & Medium \\
\hline 4 & $\begin{array}{l}\text { Physical disability } \\
\text { Total }\end{array}$ & $\begin{array}{c}28 \\
126\end{array}$ & $\begin{array}{c}8 \\
46\end{array}$ & $\begin{array}{c}578 \\
2732\end{array}$ & $\begin{array}{l}15 \\
72\end{array}$ & $\begin{array}{l}43 \\
50\end{array}$ & $\begin{array}{l}4,7 \\
21\end{array}$ & $\begin{array}{l}\text { Low } \\
\text { Medium }\end{array}$ \\
\hline
\end{tabular}

Based on Table 2, it generally shows that the description of the students' inferiority is stated in the medium category (50\%). It generally indicates that the students did tend to feel inferior. The data analysis of each indicator are natural physical form (49\%), physical appearance (52\%), physical ability (54\%), and physical disability (43\%).

The results of study about inferiority can be caused by a misperception about the students' body image (Ekbote et al., 2017). Elkind (Papalia et al., 2011) states that the Imaginary of an audience in adolescence will show an increasing and will decline as they face the adult phase. One of the reasons that cause teenagers to have inferiority feelings as they might not satisfy with their body images (Flores, Mayumi, Zapata, \& Alvarado, 2017).

The feelings of inferiority acute can lead to an emergence of a sense of inadequacy, a feeling of worthlessness, and lack of self-confidence (Jin et al., 2014). The results of previous research revealed that junior high school students have a low confidence level in the forms of teeth. They use stirrup teeth for trends, teenagers are dissatisfied with sensitive and oily facial skin, discouraged by dark skin tones, feeling inferior to body fat or thin, so adolescence experience stress when choosing the right clothes for themselves, feel having an ugly face because of acne and shame to have a short body (Muhsin, 2014). The results of Rahima, Neviyarni, \& Daharnis (2015) revealed that most adolescents obesity has a high feeling of inferiority. The results of study Maharani \& Mansur (2016) also revealed that the self-confidence junior high school students in Indonesia are on average still in the low category. The results of this study corresponding with the theory, which shows the feelings of inferiority students' in terms of physical conditions on average in the medium category.

Some other factors that could also trigger emergence feelings inferiority in adolescents are social relationships with peers (Min et al., 2014), socioeconomic status, parenting patterns (David \& Trandafira, 2012), feeling confuse about self- identity, bad live experiences (Papalia et al., 2011), anxiety, and physical appearance (Hoang et al., 2017; Hurlock, 2008; Kaluzna, 2017). Previous research suggests that peers group might have a significant influence on the student's self-image (Min et al., 2014). Also, Environmental acceptance plays a vital role in shaping adolescence's self-identity. If some students feel they are a minority in such a group community, then it might indicate a rise of inferiority feeling. Consequently, the individual would develop as an apathetic person (Flanagan, Sommers, \& Sommers, 2004). Based on these explanations, the results found in this study related to feelings of inferiority based on physical condition, founded some students have feelings inferiority in medium category.

\section{Conclusions}

In summary, the feelings of inferiority of the students in Islamic Junior High School are in a medium category, which was seen from the natural physical form, physical appearance, physical ability, and physical disability. For the next researchers, it is probably suggested that they might extend their research sample, and be able to find other factors that could trigger the emergence of feelings inferiority in adolescents.

\section{References}

Adler, A. (1997). Understanding Life An Introduction to The Psychology of Alfred Adler (Edisi Onew). England: US Marketing Office.

Agbaria, Q., Ronen, T., \& Hamama, L. (2012). Children and Youth Services Review The Link Between Developmental Components (Age and Gender), Need to Belong and Resources of Self-Control and Feelings of Happiness, and Frequency of Symptoms Among Arab Adolescents in Israel. Children and Youth Services Review, 34(10), 2018-2027. https://doi.org/10.1016/j.childyouth.2012.03.009 
Azwar, S. (2014). Penyusunan Skala Psikologi (Ke-II). Yogyakarta: Pustaka Pelajar.

Brachfeld, O. (2001). Inferiority Feelings in The Individual and The Group. Francis: The Taylor \& Francis eLibrary.

Centi, P. J. (1993). Mengapa Rendah Diri? Yogyakarta: Kanisius.

David, R., \& Trandafira, M. (2012). "I Want to Fly" - Initiating a Program of Psychological Counseling in order to Mitigate The Inferiority Complex of Teenagers in Disadvantaged Families. Procedia Social and Behavioral Sciences, 33(11), 533-537. https://doi.org/10.1016/j.sbspro.2012.01.178.

Ekbote, V., Shimpi, A., Rairikar, S., Shyam, A. K., \& Sancheti, P. (2017). Perception of Body Image to Fat Content in Adolescent Girls and Boys. Journal Youth Adolescent Health, 4(2), 30-33.

Feist, J., \& Feist, G. J. (2011). Teori Kepribadian (edisi Ketu). Jakarta: Salemba Humanika.

Feldman, R. S. (2012). Pengantar Psikologi. Jakarta: Salemba Humanika.

Ferguson, S. L., \& Hull, D. M. (2017). Personality Profiles: Using Latent Profile Analysis to Model Personality Typologies. Personality and Individual Differences, 122(2018), 177-183. https://doi.org/10.1016/j.paid.2017.10.029.

Flanagan, Sommers, J., \& Sommers, R. (2004). Counselling and Psychotherapy Theories in Context and Practice (Skills, Strategies, and, Techniques). United States of America: John Wiley \& Sons, Inc.

Flores, F., Mayumi, K., Zapata, M. A., \& Alvarado, G. F. (2017). Association Between Body Image Dissatisfaction and Depressive Symptoms in Adolescents. Journal Scielo, 39(4).

Friedman, \& Schustack. (2008). Kepribadian: Teori Klasik dan Riset Modern (Edisi Ke-III). Jakarta: Erlangga.

Hidayat, D. R. (2015). Teori dan Aplikasi Psikologi Kepribadian dalam Konseling (Edisi Ke-II). Bogor: Ghalia Indonesia.

Hoang, N., Cytrynbaum, C., \& Scherer, S. W. (2017). Patient Education and Counseling Communicating Complex Genomic Information : A Counselling Approach Derived from Research Experience with Autism Spectrum Disorder. Patient Education and Counseling, 23-26. https://doi.org/10.1016/j.pec.2017.07.029.

Hurlock, E. B. (2008). Psikologi Perkembangan Suatu Pendekatan Sepanjang Rentang Kehidupan (Edisi Ke-V). Jakarta: Erlangga.

Iltizamah, \& Sastroatmodjo. (2017). Pengaruh Penggunaan Strategi Realita dalam Konseling Kelompok terhadap Rasa Rendah Diri Siswa Kelas XII-IPA SMA Dr. Soetomo Surabaya. Jurnal Helper, 1(33).

Jin, H., Park, J., Fava, M., Mischoulon, D., Hoon, J., Seong, S., ... Je, M. (2014). Feelings of Worthlessness , Traumatic Experience, and Their Comorbidity in Relation to Lifetime Suicide Attempt in Community Adults with Major Depressive Disorder. Journal of Affective Disorders, 166, 206-212. https://doi.org/10.1016/j.jad.2014.05.010.

Kaluzna, A. (2017). The Community Feeling versus Anxiety, Self-Esteem and Well-Being. Polish Psychological Bulletin, 48(2), 167-174.

Kartika \& Nurihsan, J. (2009). The Effectivity of Self-Management to Reduce Inferiority Feeling.

Maharani, L., \& Mansur, M. (2016). Efektivitas Konseling Puisi sebagai Media Bimbingan dan Konseling dalam Meningkatkan Rasa Percaya Diri Peserta Didik Kelas VII SMPN 24 Bandar Lampung Tahun Ajaran 2015/2016. Jurnal Bimbingan Dan Konseling, 3(2), 201-215.

Min, Y., Lee, D., \& Lee, H. (2014). The Effect of Self-Compassion on Emotions When Experiencing a Sense of Inferiority Across Comparison Situations. Procedia - Social and Behavioral Sciences, 114, 949 953. https://doi.org/10.1016/j.sbspro.2013.12.813.

Muhsin, A. (2014). Studi Kasus Ketidakpuasan Remaja Putri terhadap Keadaan Tubuhnya (Body Image Negative pada Remaja Putri). Universitas Negeri Yogyakarta.

Papalia, D. E., Old, S. W., \& Feldman, R. D. (2011). Human Development (Psikologi Perkembangan). Jakarta: Kencana.

Rahima, R., Neviyarni, S., \& Daharnis. (2015). Penerapan Konseling Kelompok Adlerian untuk Mengurangi Rasa Rendah Diri Siswa Obesitas. Jurnal Konselor, 4(1), 42-49.

Santrock, J. W. (2012). Life-Span Development, Perkembangan Masa-Hidup Edisi Ketigabelas Jilid I. Jakarta: Erlangga.

Suryabrata, S. (2012). Psikologi Kepribadian. Jakarta: Rajawali Pers. 